\title{
POISONS, TRIALS AND EXPERTS:
}

\author{
PERE MATA I FONTANET (1811-1877) AND SPANISH NINETEENTH-CENTURY \\ TOXICOLOGY \\ Mar Cuenca-Lorente \\ (Institute for the History of Medicine and Science López Piñero, \\ University of Valencia) \\ maria.mar.cuenca@uv.es
}

\begin{abstract}
Pere Mata $i$ Fontanet (1811-1877) was the most important Spanish toxicologist in the nineteenth-century. However, he remained an invisible character outside Spanish borders. He was the author of the most influential Spanish treatise on legal medicine and toxicology, which had six editions but was never translated. His treatises did not include experimental results but rather a rhetorical discussion and a place where he discussed and claimed for changes to be made in those new sciences. His participation in famous trials such as poisoning cases contributed to increase his claimed authority as an expert. This paper will show that it was precisely during those trials, when experts had to face the puzzling questions of lawyers and jurors, that toxicology was built.
\end{abstract}

KEYWORDS: Toxicology, poison, nineteenth century, Pere Mata, legal medicine

\section{INTRODUCTION}

Poisoning crimes, despite not being one of the more common forms of homicide in the nineteenth-century, generally produced a large social impact and sometimes, led to long-lasting discussions among experts. ${ }^{1}$ Around the middle of 1844 , a poisoning case,

1 Two of the most well-known poisoning cases are the William Palmer case and the "Lafarge affair," which have been deeply studied by the historians Ian Burney and José Ramón Bertomeu. In both of them, their experts, Alfred Swaine Taylor (1806-1880) and Mateu Orfila (1787-1853), took part in frequent discussions concerning the used poison and the methodology that was employed to prove the poisoning cases. In the case of Alfred S. Taylor, he published a report after the trial 
referred as "causa María Bonamot," attracted the attention of both the Spanish medical profession and the daily press. The interest in this then-alleged poisoning case lasted for several months. ${ }^{2}$ This is reflected in the numerous pages that these publications devoted to the medical reports and the discussions generated by the conclusions obtained by the members forming the commission, previously appointed in cases where a violent death was suspected. Also, the case was used as an example of a real poisoning case in one of the most important Spanish toxicology textbooks, Compendio de Toxicologia generaly especial, written by Pere Mata i Fontanet (18111877). ${ }^{3}$

Figure 1. Pere Mata i Fontanet.

[Source: Fons Salvador Vilaseca. Institut Municipal Museus de Reus (IMMR)]

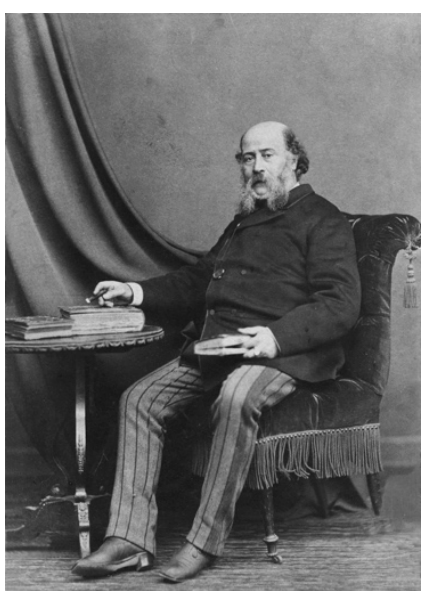

in order to show his points of view and the issues that had been controversial during the trial. Alfred Taylor, On poisoning by Strychnia, with comments on the Medical Evidence given at the Trial of William Palmer (London: Longman, 1856). Ian Burney reproduces the main aspects of this trial in his article: Ian Burney, "A poisoning of no substance: the trials of Medico-Legal Proof in Mid-Victorian England," Journal of British Studies, 1999, 38 (1): 59-92.

${ }^{2}$ Both periodical and medical press included news about the Bonamot's poisoning case during several months. Whilst the medical press payed more attention to the scientific debates, the general press offered details about the dates of the trial and brief explanation of the case. Different newspapers from the Madrid area, where the alleged poisoning case took place, published over a period of about two years detail the case. Some examples of the newspapers are: El Espectador, 1846, 1401: 4; El Heraldo, 1846, 1806:4; El Español, 1846, 472: 4 and Eco del Comercio, 1846,1033: 4.

3 Pere Mata, Compendio de Toxicología General y Especial (Madrid: Imprenta de Don Joaquín Merás y Suárez, 1846), pp. 485-492. This book was the third volume of his textbook on legal medicine, Tratado de medicina y cirugía legal (Madrid: Imprenta de Don Joaquín Merás y Suárez, 1846), which had six editions (1844, 1846, 1857 , 1874-5, 1903-4). This poisoning case was mentioned in all editions except the 1844 edition, year in which the case took place.

HoST - Journal of History of Science and Technology 11, pp. 75-96 DOI 10.1515/host-2017-0005 


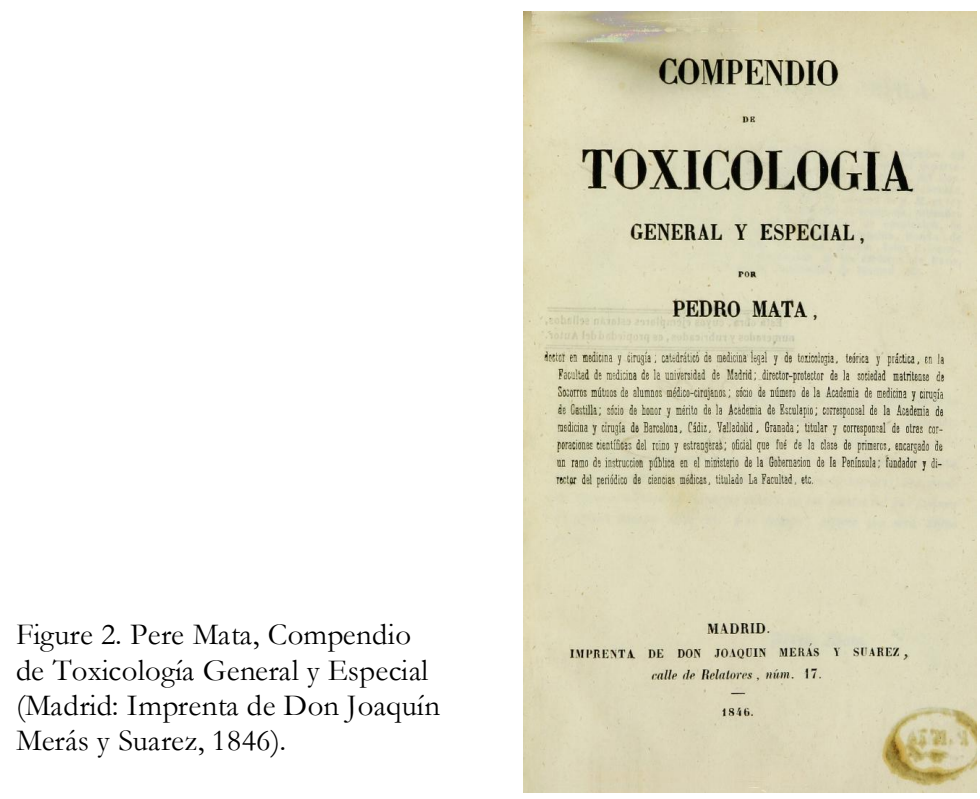

Two factors definitely contributed to the notoriety of the case: the dates on which the trial took place (only one year after the establishment of the chair of Legal Medicine in the faculties of science of Madrid and Barcelona), and the involvement as experts of some of the most influential figures of Spanish legal medicine and toxicology, such as Pere Mata. ${ }^{4}$ Through this case we can pinpoint how the scientific discussions went beyond the limits of the laboratory and academia and became a public confrontation with continual accusations between some of the main experts involved. It also allows us to analyze the role of an expert from the so-called periphery, but more generally, it offers an ideal framework to explore the configuration of the emerging Spanish toxicology in the mid-nineteenth-century. ${ }^{5}$

4 The existing literature on Pere Mata is very wide and diverse. Some references about his biography are: José Luis Patier de la Peña, La introducción de la medicina legal en España: Ideología y obra del Dr. Pedro Mata i Fontanet (PhD Thesis, Madrid: Universidad Autónoma de Madrid, 1982); Joaquim Toro Mérida and Ascensión Prieto Alberca, Pedro Mata i Fontanet: vida, obra y pensamiento (1811-1877) (Prial: Editorial Técnica, 1987). See also Mar Cuenca-Lorente, El veneno de María Bonamot: juicios, peritos y crimen en la España del siglo XIX (Ph.D. Thesis, València: Universitat de València, 2015).

5 The new historiography about experts is intrinsically related to the circulation of knowledge, scientific travels and the reformulation of concepts such as "center and periphery". These studies claim for the consideration of the periphery as an active place in the production of knowledge. Thus, teaching, textbooks or legal systems existing in a determinate context play a crucial role to define these practices and in 
First, I will focus on the crime of poisoning itself. Such crimes enjoy a special consideration both by society and the press. A huge range of popular images have been linked to poisoning crimes: the diverse definitions of poison, the fear they are able to provoke, and the many associations of the criminal with a specific gender and social class. ${ }^{6}$ Even though they do not reflect a high percentage of the total number of homicides, they provoke social alarm and generate a great expectation, as can be seen in famous poisoning cases such as those of Madame Lafarge in France or William Palmer in England. $^{7}$ In the nineteenth century, toxicologists knew how to profit from this situation and they emerged as the only experts capable of fighting against this special type of crime. ${ }^{8}$ The press

the different ways that science is appropriated and popularised. This multidirectional flow of objects, figures and experimental practices allows the exploration and consolidation of a local scientific culture. An ambitious proposal was the one carried out by the STEP group (Science and Technology in the European Periphery), which was formed in 1999 by researchers belonging to different European universities. As a result of their meetings, important publications dealing with this topic have been produced. See: Kostas Gavroglu et al., "Science and Technology in the European Periphery. Historiographical Reflections," History of Science, 2008, 46: 153-175. Thanks to these initiatives, a great number of studies from countries that traditionally have received less attention have become known. A wonderful example is the special issue that was published in 2006, which includes studies from countries such as Hungary, Russia, Greece, Portugal and Spain: "Science Textbooks in the European Periphery: Science and Education," Science \& Education, 2006, 15:7-8.

${ }^{6}$ Some authors have pointed out the need to carry out comparative analysis that allows for studying aspects such as violent and non-violent criminality, time, and gender, in order to avoid this biased view. See: Anne Marie Kilday, David Nash, Histories of crime: Britain, 1600-2000 (Basingtoke, Palgrave Macmillan, 2010). About gender and social class in poisoning crimes, see: Katherine Watson, Poisoned Lives: English Poisoners and their Victims (London, Hamblendon and London, 2004) p. XIII. The definition of poison was also a topic of debate during the nineteenth-century. About the definition of poison see: Bettina Wahrig, "Organisms that Matter. German Toxicology 1785-1822 and the Role of Orfila's Textbook," in Chemistry, Medicine and Crime: Mateu Orfila (1787-1853) and his times, eds., José Ramón Bertomeu-Sánchez and Agustí Nieto-Galán (Sagamore Beach MA: Science History Publications, 2006), 153-182.

${ }^{7}$ Both trials are representative enough to show people's fascination with this type of crime. For instance, more than 20,000 people attended William Palmer's execution in 1856. About both cases see the published works by Ian Burney and José Ramón Bertomeu. Ian Burney, Poison, Detection and the Victorian Imagination, (Manchester: University Press, 2006) and José Ramón Bertomeu, La verdad sobre el caso Lafarge: Ciencia, justicia y ley durante el siglo XIX (Barcelona: El Serbal, 2015).

8 Specialised knowledge was required in order to succeed in solving a poisoning case because sophisticated chemical tests and experience in their use were crucial to achieve conclusive results. The toxicologists appeared as the group that would take up that empty space. However, this pointed out another issue: the confrontation between areas such as pharmacy or chemistry. Toxicologists needed HoST - Journal of History of Science and Technology 11, pp. 75-96 DOI 10.1515/host-2017-0005 
helped to expand the interest in these crimes by periodically publishing news about the cases and allowing readers to participate in their resolution. Additionally, this crime was narrowly associated to stereotyped images that linked women and poverty to poison. Popular images of poisoning usually include stereotypes that can be quite different from the reality shown by some statistics, even considering the difficulties implied when working with those sources. In this popular profile of poisoning crimes, it is not difficult to find statements such as "a feminine crime" or a "crime of the poor," probably influenced by the cases that have become notorious. The term "poison" itself was not well-defined. Then, providing a medical and scientific definition of the term poison was crucial in order to establish a new disciplinary space for toxicology, as it allowed reorganisation of the borders between criminal poisoning and accidental intoxication.

Considering all these factors, it is clear that by the mid-nineteenthcentury there was evident need for experts who could prove in the courtroom the presence of poison. The nature of the poison (both availability and chemical composition), specialised background of experts and their ability to show proof-in a convincing way-to lawyers and jurors were key elements of success when confronting other experts. In the second part of the article I will examine the role played by one of these experts, Pere Mata i Fontanet. Tracing Mata's biographical path, we shall see how Mata was able to build his authority as an expert in nineteenth-century Spain. As did many other experts of his period, Mata had to face the characteristics of nineteenth-century Spain: instability of institutions, continuous educational reforms, and political repression, which, as in his case, provoked many scientists to go into exile. 'However, Mata knew

to construct their domain and this implied that they needed to separate themselves from other competing disciplines. See: Frédéric Chauvaud, Les experts du crime. La médecine légale en France au XIXè siècle (Paris: Aubier, 2000), pp. 32-38. For instance, in the Spanish case, Pere Mata criticised the different backgrounds in the group of professionals that took part in solving a poisoning case and pointed out the coexistence of different expert types, acknowledging the need to prepare experts who could interpret the three types of proofs that were used at the time (clinical diagnosis, post-mortem examination and chemical analysis). Pere Mata, Vade Mecum de Medicina y Cirugía Legal (Madrid: Imprenta Calle de Padilla, 1844), p. 540.

9 The historian José María López Piñero stated that in the nineteenth-century, politics was essential to understand the changes produced in the teaching of sciences. He also pointed out that a network of circulation of knowledge was established between France and Spain as the incessant changes in the government provoked many scientists to leave. At their return, they imported techniques and knowledge learnt abroad, besides providing themselves with a certain degree of prestige and authority to introduce reformist measures. See: José María López 
how to turn many of these situations to his favour, with him becoming the most influential Spanish toxicologist in the nineteenth-century. Competent management of both political and some alleged relationships were vital to the construction of his authority and credibility. He was also a very prolific author, and his textbooks were essential to consolidate both his position and the new toxicology. He employed his publications as a space in which to express his views and demands for the new legal medicine and toxicology. In the last part of the article I will briefly analyse how all the above-mentioned factors converged and a new community of toxicologists started to become consolidated as a result.

\section{INVISIBLE CRIMES?}

The combination between crime and trial generally produces a high impact in the media, in the past as now. ${ }^{10}$ As mentioned above, poisoning crimes represented a very low percentage of the total number of homicides. ${ }^{11}$ However, the panic they generated cannot be compared to other forms of crime, and some authors have referred to them as a poisoning epidemic, and even as something contagious. ${ }^{12}$ Those fears were produced by the secret character of these crimes and the difficulty of protecting against them, as on many occasions they were perpetrated in the victim's home and without any witnesses. Exaggerated or not, the truth is that the number of known cases was increasing from the 1820s and had its peak during the mid-nineteenth-century. ${ }^{13}$

Piñero, "La ciencia en la España del siglo XIX," Ayer 7, 1992: 218.

${ }^{10}$ In the last decades there has been a notable increase in interest for the history of crime. One of the most influential books is the one published by the British authors David Nash and Anne-Marie Kilday: Anne-Marie Kilday; David Nash, Histories of crime: Britain 1600-2000 (Basingtoke: Palgrave Macmillan, 2010).

11 The available statistics show that poisoning crimes did not represent more than $2-3 \%$ of the total number of homicides. However, the use of statistics and the difficulties implied when working with poisoning cases should make us be careful regarding this source. Some interesting studies have been those carried out by Monique Septon in Belgium: Monique Septon, Les femmes et le poison. L'empoisonnement devant les juridictions criminelles en Belgique au XIXE siècle (1795-1914) (PhD Thesis, Milwaukee, Wisconsin: Marquette University, 1996) and Katherine Watson in England: Katherine Watson, Poisoned Lives: English Poisoners and their Victims (London: Hambledon and London, 2004).

12 The relationship between press and poisoning is widely analysed in Burney, Poison, Detection, and the Victorian Imagination, pp. 11-39, and in Mark Essig, Science and Sensation: Poison murder and forensic medicine in Nineteenth-Century America (Ph.D. Thesis, Ithaca, NY: Cornell University).

${ }^{13}$ For some data regarding the English case, see Katherine Watson, Poisoned lives: HoST - Journal of History of Science and Technology 11, pp. 75-96 DOI 10.1515/host-2017-0005 
Although arsenic was the most commonly used poison in the nineteenth-century, as some authors have pointed out, it was not the one causing major difficulties to toxicologists in its identification. ${ }^{14}$ Other poisonous substances were used as well. For instance, even considering significant differences in their use throughout various countries, some statistics show that opium and phosphorus were commonly used by criminals. In France, in late 1830s, two thirds of all poisonings were conducted through the use of arsenic, while the statistics available for England in the study carried out by Katherine Watson, indicate that of the 540 cases that occurred between 1750 and 1914,

Arsenic was the poison used in $44 \%$ of the cases. ${ }^{15}$ Therefore, arsenic was the star poison in any textbook of nineteenth-century toxicology, it was the substance which occupied the most pages, and the prime suspect when experts were faced with an alleged case of poisoning. After the progressive discovery of the alkaloids in the first third of the nineteenth century and their introduction into therapeutics, they became a new weapon suitable for criminals to use. Reliable detection of these substances in cases of poisoning posed new challenges for toxicologists, and thus determined the high number of efforts towards finding new detection methods. ${ }^{16}$

English Poisoners and their Victims (London: Hambledon and London, 2004), 32. For a comparison between the poisons used in the English and French cases, see: Sacha Tomic, "Alkaloids and Crime in Early Nineteenth-Century France," in Chemistry, medicine and crime, eds. Bertomeu-Sánchez and Nieto-Galán, pp. 261-292. Although arsenic was equally popular in both England and France, opium was more used in England and phosphorus in France.

14 Peter Bartrip, “A "Pennurth of Arsenic for Rat Poison:” the Arsenic Act, 1851, and the Prevention of Secret Poisoning," Medical History, 1992, 36 (1) 53-69; James Whorton, The Arsenic Century (New York: Oxford University Press, 2010); José Ramón Bertomeu-Sánchez, "Managing Uncertainty in the Academy and the Courtroom: Normal Arsenic and Nineteenth-Century Toxicology," Isis, 2013, 104 (2):197-225.

${ }^{15}$ Despite the fact that this data corresponds to the English and French cases, they show how arsenic was by far the most used among all poisons. In the Spanish case, no similar statistics have yet been found, but some relevant data is offered in the record of medico-chemical analysis performed in 1857. This shows that there were fourteen poisoning cases, and in seven of them, arsenic was the poison used. Perez de Petinto y M. Bertomeu, "Comienzo y actualidad (en 1951) de la trayectoria corporativa Médico-forense," Revista Española de Medicina Legal, 1999, 23 (14): 8687. Some journals published statistics but these were usually located to one city and very unspecific. For instance see: El Clamor Público, 1850, 1733: 1 and El Nuevo Observador, 1852, 1473: 3.

16 About alkaloids and crime, see: Ian Burney, "A poisoning of no substance: the trials of Medico-Legal Proof in Mid-Victorian England," Journal of British Studies, 1999, 38 (1): 59-92; Sacha Tomic, Aux origines de la chimie organique: méthodes et 
As the nineteenth-century progressed, criminals faced more barriers when perpetrating their poisoning crimes. The fight against crime was visible in the regulations for the sale of poisons and the improvement of detection methods. In Spain, the Ley de Sanidad of 1855 and a Pharmacy Act in 1860, proposed restrictions on the sale of poisons. ${ }^{17}$ These measures did not provoke the disappearance of poisoning crimes but as statistics have shown in other countries, they indicate a gradual decrease. ${ }^{18}$ Justice also had to face the challenge that poisoning crimes posed. It is clear that the diversity of legal systems highly condition the way in which a criminal threat is tackled. In Spain, the nineteenth-century was a tumultuous period by political terms, which undoubtedly hardened the development of the judicial system. ${ }^{19}$ The absence of doctors among the professionals in charge of reforming the penal codes and the use of outdated sources that did not take into consideration the most recent developments in legal medicine and toxicology motivated the critics of the most influential toxicologists of the moment. ${ }^{20}$ In their proposals, the need to create a chair to form experts who could be consulted by the judge in criminal cases was paramount. The figure of an expert in toxicology in tribunals turned into a fundamental element in nineteenth-century. They were in charge of offering their opinion and describing the facts, thus influencing the final decision taken by the judge, who lacked the necessary

pratiques des pharmaciens et des chemistes (1785-1835) (Rennes, Presses Universitaires de Rennes, 2010).

17 The Ley de Sanidad of 1855 included nine articles that referred to the selling of drugs in general. In 1860, the Pharmacy Act increased the restrictions on the selling of "dangerous drugs" and confirmed that only pharmacists could sell these drugs. See: Ley de Sanidad (28/11/1985) and Gaceta de Madrid, (24/04/1860), 115, 1-2

18 Bartrip, "A Pennurth of Arsenic for Rat Poison," 64; Watson, Poisoned Lives, p.43.

19 The Spanish nineteenth-century was very unstable in terms of politics. As a consequence, different political parties were in charge of the country's government and deterred the policies taken at each moment. During the nineteenth-century up to four different penal codes were valid (1822, 1848, 1850 and 1870), besides also two proposals that were never in force. This situation differs clearly from other countries such as France, which had been the model for Spanish legislators, where the new bases for legislation were scarcely modified during the nineteenth-century. For a general perspective about Spanish legislation: Javier Alvarado Planas et al., Manual de Historia del Derecho y de las Instituciones (Madrid: Sanz y Torres, 2006); Juan Francisco Lasso Gaite, Crónica de la codificación española (Madrid: Ministerio de Justicia, 1970). For a more detailed approach to the legislation on poisoning crime, see: Julio César Cerdeiras, Estudio bistórico y jurídico con breves consideraciones médicolegales y psicológicas del delito de envenenamiento, (Madrid: Reus, 1925).

20 Pere Mata, Compendio de toxicología general y especial, pp. 24-25; Mata, Compendio de toxicología general y particular, p. 48.

HoST - Journal of History of Science and Technology 11, pp. 75-96

DOI 10.1515/host-2017-0005 
background to determine the existence of poisoning. For experts, as we shall prove throughout the article, to participate in a trial provided a space in which they could legitimate their authority, even though it could turn out to be a double-edged sword, as their image could be damaged when confronting other experts. Trial reports from the nineteenth-century are a fantastic source to explore these issues, even though they are not so easy to find. ${ }^{21}$ For instance, they allow us to enter into the realm of the courtroom, to get to know details about the participants and the atmosphere that attracted crowds to the courtroom. But mainly, they illuminate the debates that arose during the process, which in many cases lasted for several months after the trial had ended, generating scientific controversies and confrontations among experts who had to employ all their strategies in order to obtain (or maintain) their authority. ${ }^{22}$

However, in mid-nineteenth century Spain there was not a clearly defined group of experts who could be approached by judges during a criminal case. The Catalan toxicologist Pere Mata i Fontanet was one of the authors who wrote about these issues, advocating the creation of a body of forensic doctors. ${ }^{23}$ Mata stated that many poisonings went unnoticed in Spain due to the lack of knowledge of the persons initially in charge of examining these cases. This explained, as Mata pointed out, why these crimes did not reach such a high number of cases as those produced in other countries. ${ }^{24}$ That was one of the reasons he used in order to claim

21 The difficulties in finding trial reports come from the few cases that have been deeply analysed. Those that have been explored usually belong to other criminal causes. Excellent descriptions can be found in the cases analysed by the Spanish historian Ricardo Campos, mainly in one crime that took place in 1883 and that included many controversies arisen during the judicial process and that involved different institutions such as the Academy of Medicine. Ricardo Campos, El caso Morillo: crimen, locura y subjetividad en la España de la Restauración (Madrid: Consejo Superior de Investigaciones Científicas, 2012).

22 Even difficult to find, very detailed descriptions that offer lots of detail can be found in trials as the one studied by Ricardo Campos, El caso Morillo: crimen, locura y subjetividad en la España de la Restauración (Madrid: Consejo Superior de Investigaciones Científicas, 2012), pp.134-135. Other excellent sources are fiction novels. In one of the first crime fiction novels in Spain published in 1853, the journalist and writer Pedro Antonio de Alarcón, reconstructed a judicial case in the same years as the Bonamot poisoning case. Pedro Antonio De Alarcón, El Clavo: Causa Célebre (Madrid: Rodríguez Serra, 1853), p.89.

23 Pere Mata, Del secreto en Medicina. Oración inaugural pronunciada en la apertura del curso académico de 1848 a 1849 de la Universidad literaria de Madrid el día 1 de octubre de 1848 (Madrid: Imprenta de José María Ducarzal, 1848), p. 28.

24 Pere Mata, Compendio de toxicología general y especial, pp. 7-8. Mata argued in his textbook that even though it was not common to hear about poisoning cases in Spain, it did not mean that they were not taking place. One of the reasons for this 
the need for the creation of a specific university chair for toxicology and legal medicine.

By following Pere Mata's path, I will discuss how Spanish nineteenth-century toxicology was shaped. He took a vital role in most of the determining issues in the process of making a community of experts. He designed one of the most important university reforms and participated in the establishment of the first chairs in legal medicine in the faculties of Medicine in the midnineteenth-century. Furthermore, he wrote several treatises on this topic and in many others. ${ }^{25}$ As I have already pinpointed, he wrote several critiques regarding the role of experts in the courtroom and, finally, he actively took part in the creation of a body of forensic doctors in 1862.

absence was due to the first exam carried out on the body and the lack of interpretation of facts by those first doctors performing the exam. The lawyer and historian Julio César Cerdeiras pointed out in his analysis about poisoning crime that most of the crimes were ignored by society and also by the judiciary and that the available statistics did not offer relevant conclusions. Julio César Cerdeiras, Estudio bistórico y jurídico con breves consideraciones médico-legales y psicológicas del delito de envenenamiento, (Madrid: Reus, 1925), p. 4. If we take into consideration the role played by the Spanish press, one can observe that poisoning crime was seen as something unusual even though it was also seen as disquieting. Some authors described it as "a rare crime in comparison with other nations," and comparisons with the higher prevalence of crimes in France and England were quite common. Some examples can be found in Spanish newspapers from 1847 and 1848: El Espectador, 1847, 355:4; El Espectador, 1848, 22: 1.

25 Pere Mata was a multifaceted author, who moved between different areas of knowledge and spaces that helped to construct him as an expert toxicologist. His literary production was extensive and includes an oeuvre of political newspapers up to novels and poetry. His publications deal with topics such as psychology, medical law or philosophy. Different authors have studied Mata's contributions to other areas. For example, his relationship with literature was analysed by Antonio Ibañez Olivares, L'obra novel-lística del Dr. Pere Mata (Reus: Associació d'estudis reusencs, 1994) and his relationship with psychology has been studied by Maria Nieves López Fernández, La psicología en la obra de Pedro Mata y Fontanet (Valladolid: Universidad de Valladolid, 1992).

HoST - Journal of History of Science and Technology 11, pp. 75-96

DOI 10.1515/host-2017-0005 


\section{A NeW SPACE For LEgal Medicine AND ToXicology}

The first decades of the nineteenth-century were characterised by the numerous changes produced in the medical curricula, and it was not until 1843 that legal medicine became an independent topic, separated from other fields such as surgery or therapeutics. ${ }^{26}$ This was possible thanks to the so-called "Plan Mata," in which Pere Mata played a crucial role based on his political influence. ${ }^{27}$ Pere Mata i Fontanet was born in the Catalonian town of Reus in 1811. He studied at the Royal School of Medicine and Surgery in Barcelona during the 1830s. Very soon he became involved in politics, and was twice forced into exile in France during the late 1830s. In 1838 he went to Montpellier, and in 1839 he arrived in Paris. ${ }^{28}$ There, it is possible that he attended lessons by Mateu Orfila (1787-1853), who at that moment was the Dean of the Paris Medical Faculty and one of the most influential authors in

${ }^{26}$ For a general view about Spanish medicine in the nineteenth-century, see: José María López Piñero, "La ciencia en la España del siglo XIX," Ayer 7, 1992: 193240 and Leoncio López-Ocón, Historia de la ciencia española (Madrid, Alianza Editorial, 2003).

${ }^{27}$ From his youth, Mata was enroled in political activities, a situation that provoked both of his exiles. In the 1840 s, the political situation was favourable to his interests (he supported the liberal progressives, and he occupied different political positions in Reus, his hometown, and Barcelona. Archivo General de la Administración, AGA, (05) 001.019, caja 31/16196, exp. 966-61, Expediente personal Pedro Mata y Fontanet.

28 Little is known about Mata's activities during both exiles. Some of his biographers state that Mata's interest in literature started during those years in France, as writing novels meant a way of earning some money (Pere Barrufet i Puig, "Biografía del Dr. Pere Mata i Fontanet," Rev.Centre de Lectura de Reus, 1924, 10: 186). Another source of income during that period derived from the translations he carried out. Those translations focused on many different topics of some of the most influential authors of the moment. His first translation focused on the daguerreotype, the discovery of which had caused a great deal of expectation and had been published in French by Louis Daguerre (1787-1851) just a few months before, Pere Mata, Historia y descripción de los procederes del daguerrotipo y diorama por Daguerre (Barcelona: Don Juan Francisco Piferrer, 1839). Not long after, another translation of Pere Mata came to light. In this case, it was the work about venereal diseases published originally in 1838 by the French surgeon Philippe Ricord (1800-1889), Pere Mata, Tratado práctico de la inoculación aplicado al estudio de las enfermedades venéreas por H. Ricord (Barcelona: Don Juan Francisco Piferrer, 1840). One year later he published the translation of the different volumes of the "Recreaçao Filosofica, ou Dialogo sobre a Filosofia Natural," written by the Portuguese author Teodoro de Almeida (1722-1804). Pere Mata, Recreación Filosófica Natural por P.D. Teodoro de Almeida (Paris, Libreria de Rosa, 1841). Mata not only translated this works, labour that would continue developing when he returned to Spain, but he also included comments and showed his points of view, as he himself explained in the prologues of the books. 
toxicology. ${ }^{29}$ Mata returned to Spain in 1840 when the progressive regime rose again, and was appointed mayor of his home town, Reus. Soon after, he moved to Madrid, where he was put in charge of reforming medical studies.

This reform prompted the abolition of the Royal Schools of Surgery (from Madrid, Barcelona and Cadiz) established in the eighteenth-century. These schools had been established with the aim of reforming medical education in a period when the division between medicine and surgery was still the order of the day..$^{30}$ The instruction offered was mainly directed towards practical work and throughout the years, numerous reforms and changes in the medical studies took place. However, and even under a different name, the so-called forensic surgery, was already present in those schools of surgery, and allowed the space to open that legal medicine would occupy in the future. ${ }^{31}$ Pere Mata was a student of the Royal School of Surgery of Barcelona while all these crucial changes were taking place. ${ }^{32}$ The abolition of the Royal Schools of Surgery was followed by the creation of two faculties of Medical sciences, one in Madrid and one in Barcelona, as well as other minor schools in other Spanish towns. Although only lasting for two years, due to the excessive number of teachers and the lack of students, it provided the basis for the independence of legal medicine. ${ }^{33}$ Soon after, in 1845, another university reform, the so-called "Plan Pidal," included toxicology in the university curriculum. Thanks to some

${ }^{29}$ About Mateu Orfila, see: José Ramón Bertomeu and Josep Maria Vidal, Mateu Orfila. Autobiografia. Correspondencia (1805-1815) (Menorca: Institut Menorquí d'Estudis, 2011); Bertomeu-Sánchez and Nieto-Galán, Chemistry, Medicine and Crime and José Ramón Bertomeu-Sánchez "Classrooms, Salons, Academies, and Courts: Mateu Orfila (1787-1853) and nineteenth-century French Toxicology," Ambix, 2014, 61(2):162-186.

30 The Royal School of Cadiz was established in 1748; the one in Barcelona in 1760 and in 1787, the Royal School of San Carlos in Madrid. Their main objective was, respectively, to supply surgeons to the navy, to the army, and civil surgeons that could practice in villages and cities. See Diego Ferrer, Historia del Real Colegio de Cirugía de Cádiz (Cádiz: Universidad de Cádiz, 1983); Alfons Zarzoso, La práctica mèdica a la Catalunya del segle XVIII (Barcelona: Universitat Pompeu Fabra, 2003); José Martínez Pérez, La medicina legal en la enseñanza médico-quirúrgica en la España de la Ilustración (Madrid: Universidad Complutense de Madrid, 1988).

31 About the reforms that took place in the schools of Surgery see José Martínez Pérez, La medicina legal en la enseñanza médico-quirúrgica en la España de la Ilustración (Madrid: Universidad Complutense de Madrid, 1988). The author states that the inclusion of forensic surgery was the result of the frequent complaint of judges in regards of how the surgical-legal practice was performed.

32 Archivo General de la Administración, AGA, (05) 001.019, caja 31/16196, exp. 966-61, Expediente personal Pedro Mata y Fontanet.

33 The reform was published in: Suplemento a la Gaceta de Madrid, 1843, 3230: 1-4. HoST - Journal of History of Science and Technology 11, pp. 75-96 DOI 10.1515/host-2017-0005 
descriptions offered in Mata's treatises we can learn that during legal medicine and toxicology lessons, students learnt how to use a microscope, how to perform chemical analysis or how to carry out practical demonstrations. ${ }^{34}$ All of these skills were essential, as we shall see when having to prove the existence of poisoning. ${ }^{35}$ There is no doubt that the changes produced in the Spanish universities directly contributed to the need for having books on these subjects. The existing literature was composed mainly of French and German books. Some of the professors in charge of the teaching of those subjects criticised the lack of books that could be employed during their classes. Clearly, this was an excellent opportunity to publish their own textbooks adapted to their views on legal medicine and toxicology.

Mata also took advantage of this situation and not only occupied one of the newly established chairs - in which he remained for almost four decades_-but also published several treatises on legal medicine and toxicology. Those publications accorded him economic benefits and helped him to reinforce his academic position. In 1844, just a few months after being placed in charge of the new legal medicine, he published the Vademecum de Medicina $y$ Cirugia Legal in two volumes, intended primarily, as the author noted in the preface, for the students attending his classes. This book became a Tratado de Medicina y Cirugia Legal, which was published in 1846 and incorporated a third volume focusing on toxicology, Compendio de Toxicología. In the preface of the book, Mata stated that his intention was to provide students with some notes on the lessons taught, which he considered necessary because they did not have a textbook from which they could study. In the words of Mata, its purpose was "to fulfil an obligation imposed on the teacher, when changes in subjects, regarding both the order of subjects and the doctrines, were introduced." 36 With the idea of gathering in the Vademecum the lessons taught in the classroom, the

\footnotetext{
34 Pere Mata, Compendio de toxicología general y particular (Madrid: Carlos BaillyBaillière), p. 96.

35 During a brief period of time (between 1852 and 1858), a practical chair in Toxicology and Legal Medicine was established in the Faculty of Medicine in Madrid, partly responding to some critiques raised by Mata in reference to the impossibility for students to practice in the laboratory. However, he was not elected to be in charge of it and so he was very critical of the way the subject was taught. Pere Mata, Compendio de Toxicología general y particular (Madrid: Carlos BaillyBaillière, 1867), pp. 95-98. For a review on the different plans established during those years, see Jacint Corbella, Antecedentes históricos de la medicina legal en España (Barcelona: Publicaciones del Seminario Pere Mata, 1995).

36 Pere Mata, Compendio de Toxicología Generaly Especial, pp. IV-V.
} 
book was mainly a "didactic tool." However, this did not exclude other possible readers such as other professors and judges, highlighting the close relationship between science and law present in the field of legal medicine. Thus, by including the judges in the targeted audiences, the main role of toxicologists in the nineteenthcentury as experts in poisoning trials was reinforced. Hence, the definitions provided in the manuals, as with the term poison, for instance, and the little nuances in the expressions, were necessary since they could be interpreted in diverse ways by judges and lawyers when facing poisoning trials. Therefore, nineteenth-century judges also became toxicology book readers, reinforcing once more the need for the publication of these types of books, adapted to the legal systems existing in the country. ${ }^{37}$ The wide circulation of his textbooks in Spain can be explained mainly by three factors: the Government's recognition as "recommended for teaching;" special awards; and the labour of publishing houses. Mentions could report the author's academic progress, salary increase and other advantages such as the decrease in the cost of publication. Mata achieved one of these awards thanks to his 1846 Treatise on legal medicine. Obtaining one of these prizes also guaranteed its presence in the "recommended for teaching" lists that the Spanish Government published every year, and thus, it also guaranteed that it would be a "best-seller." 38 Finally, the success of his publications cannot be understood without taking into account the decisive contribution of its editors. From the third edition, and probably as a consequence of the great number of sales, the publishing house Charles Bailly-Baillière, the Spanish "branch" of the Baillière network, one of the most prestigious in the scientific sphere, was in charge of editing Mata's treatises. In the mid-nineteenth-century, counting on the support of a powerful publishing house such as Baillière was almost a guarantee for the wide circulation of the book, and sometimes, led to its introduction to the international

37 José Ramón Bertomeu, "Popularizing controversial science: A popular treatise on poisons by Mateu Orfila (1818)," Medical History, 2009, 53 (3): 351.

38 Mata's textbooks had to compete against translations and other textbooks published by Spanish authors. A clear example is the textbook published by the professor in charge of Legal Medicine in Barcelona, Ramón Ferrer i Garcés (18041872). However, Mata's textbooks seem to have achieved a better acceptance, as has been shown by its presence in the list of "recommended for teaching." Whilst Mata's textbook remained on it for more than twenty years (between 1846 and 1867), the textbook of Ferrer i Garcés only appeared until 1848. See: José Luis Villalaín Benito, Manuales escolares en España. Tomo II. Libros de texto autorizados y censurados (1833-1874) (Madrid: UNED, 1999).

HoST - Journal of History of Science and Technology 11, pp. 75-96 DOI 10.1515/host-2017-0005 
market, even though this does not seem to have occurred in Mata's case. ${ }^{39}$

The establishment of the medical chairs, moreover, led to an appropriate framework for the emergence of specialised journals in legal medicine and toxicology as a way of consolidating the discipline. ${ }^{40}$ Furthermore, the presence of these topics in nonspecialized journals constantly increased throughout the nineteenth-century, and it was quite common to find sections devoted to toxicology and legal medicine. ${ }^{41}$ In these journals, the most prominent authors of these topics collaborated frequently and some even went on to start their own medical journals, as in the case of Pere Mata, who called it La Facultad. Even though it only lasted for a brief period of time, from 1845 to 1847 , this publication was a very rich source of information. ${ }^{42}$ Indeed, Mata used his own journal to raise numerous critiques as to the lack of a body of forensic doctors, and even to publish proposals for its organization. It also offered him a space in which he could debate many of the controversies that nineteenth-century toxicology was facing.

As I will argue in the next section of this article, poisoning cases constituted an excellent scenario in which toxicologists could employ all their strategies. However, as I have highlighted

39 About the publishing house Bailly-Baillière see Josep Simon, "The Baillières: The Franco-British Book Trade and the Transit of Knowledge," in Franco-British interactions in science since the seventeenth century, eds. Robert Fox and Bernard Joly (London: College Publications, 2010), pp. 243-262 and Danielle Gourevitch and Jean-François Vincent eds., J.-B. Baillière et fils, éditeurs de médecine. Actes du Colloque international de Paris (Paris: BIUM, 2006).

40 The first Spanish journal devoted to legal medicine, Repertorio de Higiene Pública y Medicina Legal, came to being in 1853. A decade later, in 1863, La Gaceta Médico Forense, started publication. More information about these journals can be found in: Manuel Pérez de Petinto y Bertomeu, "Comienzo y actualidad," 9; and Jacint Corbella et al., "Nota sobre la Gaceta Médico Forense (1863). Revista pionera de medicina legal en España," Gimbernat, 1989, 12: 69-73.

${ }^{41}$ Some examples are: La Abeja Médica, La Gaceta Médica, La Gaceta Médica Catalana, La Iberia Médica and the Boletín de Medicina, Cirugia y Farmacia.

${ }^{42}$ Its first issue was published on 18 October 1845 and the last on 30 September 1847. Edited in Madrid it was published four times a month; each issue consisted of four pages. However, the second volume was smaller and consisted of only eight pages. The journal was intended to provide readers with a new perspective on the state of medicine and its progress. Its weekly publication allowed this journal to spread the latest news and discussions taking place both in Spain and other foreign countries. Numerous references to legal medicine were included, and it was usual to find discussions concerning its organisation, thus paying attention to administrative and organisational questions such as the one that I tackle in this article. Nonetheless, it included other types of questions, such as controversial poisoning cases. 
throughout, one of the difficulties was to determine who were the experts. This issue was also being debated in other countries such as Britain and France, and the lack of homogeneity within the community of experts was seen as a problem by many authors rather than an advantage, as the Spanish toxicologist Pere Mata was constantly remarking. ${ }^{43}$

The French historian Frédéric Chauvaud argues that common background, special qualifications, particular institutions and professional societies were crucial factors in the making of the community of forensic experts in France. ${ }^{44}$ In other contexts such as Britain, the emergence of legal medicine as a distinct discipline, provided an appropriate framework for the appearance of the medico-legal witness, but posed the problem of identifying who could belong to this category; in other words, who was qualified or met the required conditions to be an expert witness. Factors such as authority, locality or even financial constraints played a vital role in that election, and just a small group of experts dominated the field. ${ }^{5}$ Thus, it seems that the factor of authority and social status was a key issue when trying to solve questions such as why certain characters were chosen as experts, as we shall see in the Spanish case. ${ }^{46}$ One cannot avoid the fact that in a reciprocal way, experts benefited from this situation too. By holding an academic position and by their appearances in court, they achieved public recognition. Thus, they used their authority in many different ways, which included diverse activities, from playing leading roles in institutioncreation campaigns, to the publication of textbooks, which at the same time, conferred on them a higher status. ${ }^{47}$

\footnotetext{
43 Frédéric Chauvaud, Les experts du crime. La médecine légale en France au XIXè siècle (Paris: Aubier, 2000), p. 31; Katherine Watson, "Medical and chemical expertise in English trials for criminal poisoning," Medical History, 2006, 50 (3): 389.

${ }^{44}$ Frédéric Chauvaud, Les experts du crime. La médecine légale en France au XIXè siècle (Paris: Aubier, 2000), p. 69.

45 Katherine Watson showed in her study about Britain, the changes produced in the professional profile of experts that took part in trials for criminal poisoning, detecting three periods of development, which were at the same time related to the appearance of a particular type of witness: local surgeons-apothecaries; professional (mainly academic) chemists and toxicologists; and public analysts. See: Katherine Watson, "Medical and chemical expertise in English trials for criminal poisoning," Medical History, 2006, 50 (3): 375.

46 Ian Burney, Bodies of Evidence: Medicine and the Politics of the English Inquest, 1830 1926 (Baltimore: John Hopkins University Press, 2000), p. 9.

47 Some examples are those of William Herapath (1796-1868), who was one of the founders of the Bristol Medical School in 1832. See Katherine Watson, "Medical and chemical expertise in English trials for criminal poisoning," Medical History, 2006, 50(3): 382-383. Bernard Spilsbury (1877-1947), who led a campaign to build HoST - Journal of History of Science and Technology 11, pp. 75-96 DOI 10.1515/host-2017-0005
} 


\section{THE BIRTH OF A COMMUNITY OF TOXICOLOGISTS}

In any case of poisoning suspicion, which was determined by the circumstances in which death was produced, a tribunal had to appoint a physician to declare the medical condition of the sick or dead person. The judge, when visiting the place where the poisoning took place, had to decide what suspicious substances needed to be analysed. Then, one or two pharmacists had to be officially appointed to examine them. 48

Nevertheless, the ideal situation, as mentioned above, was not parallel to the real procedure that was followed when a poisoning case came to light. In 1844, a woman was accused of poisoning and impersonating the identity of her friend in what later became the "causa María Bonamot." The blurred circumstances in which the death took place provoked a deeper investigation of the causes of death. A heterogeneous group formed by different university professors of Pathology, Chemistry, physicians and pharmacists was appointed to elaborate the necessary reports by which the judge could decide if the death was the consequence of a poisoning crime. The by-then famous toxicologist Pere Mata was another of the scientists forming part of that commission. He criticised this procedure because of the number of professionals involved in the process. This was then used by Mata to support the recent creation of the chair in Legal medicine, a reform in which he had taken a crucial role as we have seen. In his opinion, medical practitioners required by the tribunal should have both medical and chemical knowledge because of the close relationship established between clinical diagnosis, post-mortem examination and chemical analysis. The findings could be interpreted in a more reliable way if the same person was in charge of carrying out the three basic tests considered in the case of poisoning. ${ }^{49}$

a medico-legal centre in London during the 20th century, is another example. See Ian Burney; Neil Pemberton, "Bruised Witness: Bernard Spilsbury and the Performance of Early Twentieth-Century English Forensic Pathology," Medical History, 2011, 55 (1): 58.

48 Pere Mata, Vade Mecum de Medicina y Cirugía Legal (Madrid: Imprenta Calle de Padilla, 1844), pp. 548-549.

49 Pere Mata, Vade Mecum de Medicina y Cirugía Legal (Madrid: Imprenta Calle de Padilla, 1844), pp. 548-549. The debate regarding which types of proof were necessary to determine poisoning was augmented throughout the nineteenthcentury. The majority of authors agreed in saying that to determine the existence of poisoning it was necessary to consider the results of three basic tests: symptoms, 
However, as in other European contexts, the lack of a defined group of experts that could take part in those processes and the growing specialisation, favoured the appearance of a new discipline: toxicology. ${ }^{50}$ Specialised knowledge was required in order to solve poisoning cases because sophisticated chemical tests and experience in their use were crucial to achieve conclusive results. Thus, the toxicologist appeared as the one that would take up that empty space..$^{51}$ But this pointed out another important issue: the confrontation between areas such as pharmacy or chemistry. Toxicologists needed to construct their domain and this implied that they needed to separate themselves from other competing disciplines. ${ }^{52}$ Pere Mata emphasised this division with his critics, pointing out the separation between these two professional domains (doctors and pharmacists), while defending the appearance of a new group of experts, capable of handling all types of proof.

Doctors were the only ones that had a background that included both legal medicine and toxicology. Thus, they learnt not only how to use a microscope or how to perform chemical analysis in a practical way, but, more importantly, they learnt how to use this expertise in criminal cases and to defend their arguments in front of a judge.53 Mata justified doctors who studied toxicology becoming the main experts of their study - poison - and thus, they were the only ones prepared to prove to the tribunal the absence or presence of poison. In his opinion, even though chemists or pharmacists also studied toxicology, it was a different one in the sense that they were not prepared to convince a jury, and they were just an element against the smooth running of justice. 54

post-mortem examination and chemical analysis. However, they differed in the value that each of these tests could have by itself.

${ }^{50}$ Frédéric Chauvaud, Les experts du crime. La médecine legale en France au XIXè siècle, (Paris: Aubier, 2000) p. 25. This approach is also used by Tal Golan, Laws of Men and Laws of Nature: the History of Scientific Expert Testimony in English and America (Cambridge and London: Harvard University Press, 2004), pp. 5-6.

51 Ian Burney, Poison, Detection and the Victorian Imagination, (Manchester, University Press, 2006), p. 6; Katherine Watson, Forensic Medicine in Western societies. A History, (London: Routledge, 2011), p. 46.

52 Frédéric Chauvaud, Les experts du crime. La médecine legale en France au XIXè siècle, (Paris: Aubier, 2000) pp. 32-38. The author refers to a "divided community," in which different conflicts can appear, leading to conflicts in different categories such as generational, within the speciality, between legal doctors and practitioners, or even between the urban and rural context.

53 Frédéric Chauvaud, Les experts du crime. La médecine legale en France au XIXè siècle (Paris: Aubier, 2000) pp. 111.

54 This is a reason that explains why Pere Mata's Compendium on Toxicology was HoST - Journal of History of Science and Technology 11, pp. 75-96

DOI 10.1515/host-2017-0005 
Proposals such as the one carried out by Pere Mata were crucial for the establishment in 1862 of a well-defined organizational structure that largely responded to the criticisms brought forth by the most influential toxicologists in the nineteenth century. .5

The new system considered practical training as a compulsory requirement to be able to be appointed as a forensic doctor and excluded other groups such as pharmacists or chemists. However, in certain practical cases, it advised that the judge could turn to pharmacists and chemical experts but always under the supervision of forensic doctors who would provide them with all the necessary data and would indicate the procedure used in the analysis. This fact allowed the analysis to be, when needed, repeated or confirmed on other occasions. This duty was entrusted to the professors in charge of the chairs of Toxicology and Legal Medicine. This provided the judge, who did not have the basis to determine who should take part in trials and many times based his criteria on the authority and social status of the experts, with a much more concrete selection of people eligible for the purpose. ${ }^{56}$

\section{CONCLUSION}

This article has examined the shaping of toxicology in Spain in the nineteenth-century. I have shown that Spanish toxicologists were far from being a professional community. They were rather a heterogeneous group marked by substantial differences in backgrounds and skills as well as in laboratory resources and academic authority. They tried to make themselves 'visible' by

divided in two parts. The first one included the general aspects of poisoning, and in the second part, poisons were analysed in particular. With this structure, Mata intended first to provide a general doctrine, applicable in case studies, and which could, somehow, be useful to toxicologists when facing a trial, allowing them to "illustrate" the tribunal. See: Mar Cuenca-Lorente, La toxicología en las aulas del siglo XIX: la obra de Pere Mata i Fontanet (1811-1877) in Mónica Blanco Abellán (Coord.), Actas del VII Simposio de Enseñanza de las Ciencias y de las Técnicas de la SEHCYT (Barcelona: SEHCYT), pp. 51-58.

55 Even we can find a precedent in 1855, when a Real Orden stated that the first forensic doctors were appointed in Madrid. Finally, in 1862, a Real Decreto, established the definitive creation of the Cuerpo de médicos forenses, which extended its functions to the entire Spanish territory in contrast to the proposal of 1855. See Juan Manuel Jimenez Muñoz, Historia legislativa del Cuerpo de Médicos Forenses (Valladolid: Universidad de Valladolid, 1974).

56 Gaceta de Madrid, 1862, 137:1. Some practical cases, which confirm that the procedure took place as described, can be found in Mata, Compendio de Toxicología general y particular, pp.1153-1166. 
becoming the only ones competent to make judgements on their object of study: the poison.

In the public sphere, poisoning crime was almost seen as an epidemic in most European countries. The stereotyped images associated with it contributed to creating these fears despite their scarce relevance when looking at the general statistics of crime, in which they just represented $2-3 \%$ of the total number of crimes. Journalists and newspapers largely contributed to spread this social alarm. Toxicologists found another space in which they made themselves widely known, building themselves as the ones able to solve all kind of poisoning cases, whilst the press saw an excellent opportunity to increase their sales. Conversely, the Spanish press used a different type of strategy. Poisoning crime was perceived as an uncommon crime. However, it was still possible to find a wide range of news referring to these crimes but without reaching the amount of publications in other countries.

The authority reached by some experts is represented in the Spanish case by the figure of Pere Mata. He played a crucial role in the three aspects which Chauvaud recalls as decisive in the emergence of the community of "experts of crime" in the nineteenth- century: common background, special qualifications and professional societies and institutions. First of all, an adequate academic framework for training and disciplining students was essential. In the Spanish case, the institutionalisation of the medico-legal experts was symbolised by the establishment of a chair in Legal Medicine in 1843. The fact that some professors, like in the case of Mata, held their chairs for a long period of time contributed enormously to the theoretical and practical coherence of the new toxicologists. This explains why as soon as the body of forensic doctors was formed, many of its first members had been Mata's students.

Secondly, new textbooks on toxicology and legal medicine were published in Spain during the 1840s. These books were written by the main professors occupying the university chairs in the medical school of Madrid and Barcelona. They were intended not only at their medical students but also to judges and lawyers, so these publications somehow reinforced the role of toxicologists as experts in poisoning trials. As we have seen, the growth in Spanish publications related to both legal medicine and toxicology produced after 1843, the crucial year in which the university reform carried out by Pere Mata took place. Like many other authors from his time, Mata employed in his textbooks relevant data from expert reports in poisoning trials, which conferred on him a higher degree of authority as a toxicologist. 
The third ingredient shaping the career of nineteenth-century toxicologists was their participation in trials. Courtrooms were decisive spaces for legitimation, even though some risks were faced when confronting other experts. Controversies in trials are, in fact, an extraordinary source that let us to reconstruct more general aspects of the society and the culture of the time, and that, generally, intermingle very different issues linked to politics, economy or academic disagreements. Furthermore, trials allow us to clearly visualise the weaknesses or blind spots of toxicology: different types of poison and available methods to detect them, the difficulties in their use, the lack of a clear definition of poison or the changing legal systems. In this context, the role of experts was not easy. Their reports had to be conclusive and convincingly presented to the members of the jury.

The peripheral position of Spanish science permits us, in part, to explain why Mata's textbooks were not translated to other languages or even why the poisoning cases in which he participated did not become widely popular and were soon forgotten. This difference is evident when comparing Mata to other toxicologists such as Mateu Orfila. However, some of the issues analysed here confirm that "invisible" characters outside Spanish borders, such as Pere Mata, are excellent sources that help to shed light on the shaping of nineteenth-century toxicology and the role played by its experts. For instance, Mata's biographical path and his treatises offer many details about the circulation and appropriation of different theories, objects or chemical tests, the terminology employed or the inclusion or exclusion of controversies and debates taking place in other contexts. Besides that, it helps to reconstruct what a nineteenth-century courtroom was like, and the relationships that were established among the judicial, academic and politic spheres. 


\section{ACKNOWLEDGEMENTS}

I am very grateful to José Ramón Bertomeu Sánchez (University of Valencia) for his insightful observations and support. I am also indebted to Katherine Watson for all the suggestions made during my stay in Oxford Brookes University (UK). The research for this article was supported by a grant (JAE-predoc) from the Consejo Superior de Investigaciones Científicas (CSIC); it is part of a larger study on nineteenth-century toxicology funded by the Spanish Government (HAR2012-36204-C02-01/HIST). Publishing expenses of this article were paid in the context of the project UID/HIS/00286/2013. 